[Regular Paper]

\title{
Enhanced Oil Recovery from UAE Limestone Reservoirs Using Bacteria Flooding, an Experimental Approach
}

\author{
Abdulrazag Y. ZeKRI*, Reyadh AlMEHAIDEB, and Omar ChaAlal \\ Chemical \& Petroleum Engineering Dept., Faculty of Engineering, UAE University, P.O.Box 17555, Al-Ain, United Arab Emirates
}

(Received September 11, 2000)

\begin{abstract}
This project investigates the use of bacteria, which is a minor cost material, to improve the oil recovery from UAE limestone reservoirs. The work focused initially on the study of the interfacial tension (IFT) between crudes from four different UAE reservoirs (AH, UZ, St, and UAD) and a thermophilic microbial solution. The bacteria were obtained from local water tanks. The system temperature was varied between $30-100^{\circ} \mathrm{C}$ and salinity ranged from 0 to $100,000 \mathrm{ppm}$. Bacteria solution tertiary core flooding experiments were then performed using carbonate rocks at reservoir conditions without injection of nutrient with the bacteria during the core flooding experiments. A good amount of effort was directed, throughout the work, to characterize the bacteria used and identify the mechanism by which bacteria work to improve the oil recovery.

Results of these laboratory studies showed an abrupt reduction in IFT at high salinity and high temperature (i.e. reservoir condition) for all studied systems except for the St crude, which was sulfur rich. The IFT decreased from 40 to $0.07 \mathrm{dyn} / \mathrm{cm}$ for most of the studied systems. Also, tertiary bacteria flooding at reservoir conditions, on average, resulted in an incremental oil recovery of 15 to $20 \%$ of the pore volume.
\end{abstract}

\section{Introduction}

Microbial enhancement of oil recovery (MEOR) has recently received good attention in the oil industry. In situ MEOR processes involves the injection of microorganisms and suitable nutrients into the reservoir. The use of microorganism to enhance oil recovery has for many years been considered as possible by many investigators. Beckman ${ }^{1)}$ realized that bacteria are capable of producing oil as early as 1926. Zobell ${ }^{2)}$ performed the first detailed work of MEOR in the 1940's. Successful field trials, in later years, have been reported from the US, Eastern Europe, and Australia as indicated in Refs. 3 and 4. Based on the fact that MEOR processes were recognized nearly 70 years ago, one would think that this technology is in wide use today. On the contrary, the general perception is quite the opposite. The negative perception on the use of bacteria for EOR has been attributed to inadequate methods for transfer of technology5). MEOR processes are potentially cost effective and particularly well suited for today's economic climate. Portwood ${ }^{5)}$, after review of hundreds of projects, concluded that the cost of MEOR process ranges from US $\$ 0.25$ to $\$ 0.50$ per barrel of oil produced at the time MEOR begins, and does not go up as oil production increases. The total cost of incremental oil produced from MEOR is only about US $\$ 2.00$ per barrel. In addition, MEOR proc-

* To whom correspondence should be addressed. esses are considered environmentally friendly as verified by tests conducted by public health laboratories that reported that the mixed culture of bacteria is safe to handle and poses no threat to plants, animals, or human beings ${ }^{5)}$.

Microorganisms used for MEOR processes rely on microscopic oil displacement for improving the efficiency of oil recovery. The most common species are those of Bacillus and Clostridium. These microorganisms have a greater potential for survival under petroleum reservoirs' harsh environmental conditions than other species because they produce in situ spores, which are dormant, resistant forms of the cells that can survive under stressful environmental conditions. Clostridium species produce surfactants, gases, alcohols, and solvents, whereas some Bacillus species produce surfactants, acids, and some gases. In the MEOR process, it is vital that microorganisms can travel through the porous media and mobilize oil.

Laboratory research has shown that microbial products can change the chemical and physical properties of oil, and can selectively plug high permeability zones, which results in improvement in volumetric sweep efficiency $^{7)}$. Once the bacteria are in place, a designed volume of nutrients may be injected into the reservoir to support in situ metabolism of the bacteria. The result of this metabolism is the production of cellular mass capable of initiating physical plugging. The physical plugging results in a reduction of the original permeability and can be expressed as the ratio of 
impaired to original permeability. Continuous injection will result in a diversion of the injected fluid from closed high permeability zones to upswept zones and significant improvement in overall sweep efficiency. Microorganisms that produce gases as $\mathrm{CO}_{2}, \mathrm{~N}_{2}, \mathrm{H}_{2}$, and $\mathrm{CH}_{4}$ can improve oil recovery by increasing reservoir pressure and by swelling individual trapped oil droplets and reducing oil viscosity due to the dissolution of above gases in the oil. Three phase relative permeability studies have shown that the residual oil saturation can be reduced by the presence of a gas in waterwet systems ${ }^{7}$. Another mechanism microorganisms have shown is emulsification of crude oil during flow in a porous medium. The solvents that microorganisms produce are typically low molecular weight alcohols and ketones. These compounds promote emulsification. Microbes also produce surfactants that can lower oil-water interfacial tension (IFT) thus causing emulsification. Cooper et al. ${ }^{8)}$ isolated a natural lipid bio-surfactant from the anaerobic Clostridium Posteurianum, and anaerobic bio-surfactant produced from Bacillus. Bacillus Licheniformis also produce a surfactant under anaerobic conditions. An increase in actual fluid velocity within porous media results from fluid being diverted into smaller pores due to bacterial plugging. The drop in interfacial tension and increase in fluid velocity both combine to increase the capillary number. Increased capillary numbers are associated with reduction of residual oil saturation. Some microbial species can also significantly improve oil production by helping to remove suspend debris and paraffins from near-wellbore region ${ }^{9}$. In carbonate formations or sand stone rocks with carbonaceous cementing materials, acid-producing microbes can increases permeability of rocks and thereby improve oil recovery.

Rouse et $a{ }^{10}{ }^{10}$ concluded that there is no experimental evidence that the MEOR process using powdered microbes and starch consisting of Acinetobacter Venospecre group II and Coryneform results in oil production in excess of that provided by water flooding due to the absence of enough oxygen required to generate either surfactant and or polymer in situ. Other investigators, however, have concluded that viable microorganisms can penetrate porous media, produce chemicals and gases and preferentially plug high permeability zones, which improve oil recovery significantly. Chisholm et al. ${ }^{11)}$, Yonebayashi et al. ${ }^{12)}$, Myers and Samiroden ${ }^{13)}$, Jenneman et al. ${ }^{14), 15)}$, Torbati et al. ${ }^{16)}$, Jack et al. ${ }^{17)}$, Bryan and Douglas ${ }^{18)}$, and Raiders et $a .^{19)}{ }^{21)}$ have all studied the effects of viable microbes in the porous media.

The main objective of this study is to investigate the use of bacteria, which is a minor cost material, to improve the oil recovery from UAE limestone reservoirs, and to identify the mechanisms contributing to enhance the recovery of the process.
Table 1 Description of Limestone Cores

\begin{tabular}{cccccc}
\hline Core No. & $\begin{array}{c}\text { Core } \\
{[\mathrm{code}]}\end{array}$ & $\begin{array}{c}\text { Length } \\
{[\mathrm{cm}]}\end{array}$ & $\begin{array}{c}\text { Diameter } \\
{[\mathrm{cm}]}\end{array}$ & Porosity & $\begin{array}{c}\text { Permeability } \\
{\left[10^{-3} \mu \mathrm{m}^{2}\right]}\end{array}$ \\
\hline 1 & BF1 & 3.96 & 2.2 & 0.20 & 2.66 \\
2 & BF2 & 3.89 & 2.2 & 0.22 & 64.0 \\
3 & BF3 & 3.96 & 2.21 & 0.26 & 19.0 \\
4 & BF5 & 3.99 & 2.21 & 0.16 & 1.7 \\
5 & S4 & 7.74 & 3.81 & 0.2 & 23.9 \\
6 & SF5 & 6.02 & 3.81 & 0.06 & 0.5 \\
\hline
\end{tabular}

\section{Description of Experiments}

\section{1. Materials}

\section{1. 1. Bacteria}

Two strains of bacteria rounded and rod shape type, both belonging to the Bacillus family, were obtained from the UAE local hot water streams. These bacteria were unique in their tolerance of the high temperature and salinity conditions prevailing in the UAE environment.

\section{1. 2. Medium}

The growth medium was prepared in $10,000 \mathrm{ml}$ sterilized bioreactor. The bioreactor contained $0.1 \mathrm{l}$ of indigenous microbial solution and $3.9 l$ of $5 \% \mathrm{NaCl}$ solution. In this medium, $10 \mathrm{~g}$ of nutrient (containing bouillon and yeast-extract) was added. The medium was well mixed and bacteria count was taken before using the microbial solution in any experiment. This medium was repeatedly prepared prior to conducting all of the reported experiments in this project to insure having fresh and the same bacteria concentration, which was around $10^{5} \mathrm{cells} / \mathrm{ml}$, at the start of the experiment.

\section{1. 3. Rock and Fluids}

Limestone cores obtained from outcrops at Hafeet mountains (Al-Ain, UAE) were cut on average into $2.2 \times$ $3.89 \mathrm{~cm}, 3.81 \times 7.74 \mathrm{~cm}$, or $3.81 \times 6.02 \mathrm{~cm}$ cylinders using a core cutting device. The porosity and permeability of these cores are listed in Table 1. Crude oil was obtained from different United Arab Emirates oil fields (AH, UAD, St, and UZ). The crude oil properties are presented in Table 2.

\section{2. Apparatus}

\section{2. 1. Bioreactor}

This reactor is an air curtain driven fluidized bed reactor ${ }^{9}$. It is used to generate the live microbial solution for injection experiments. Compressed air is injected into the reactor through a series of perforations in a transverse tube in order to create fluid circulation with an air curtain. This system provides for bacteria an efficient aeration technique that is non-intrusive and is particularly helpful for growing filamentous bacteria. The location of the air curtain, as well as the flow of the compressed air, was optimized. Air was supplied to the reactor through a transverse tube with equally 
Table 2 Crude Oil Properties

\begin{tabular}{|c|c|c|c|c|}
\hline Property/Crude & $\mathrm{AH}$ & $\mathrm{UZ}$ & St & UAD \\
\hline API & 39.2 & 40 & 39.5 & 34 \\
\hline Viscosity @bp & 0.28 & 0.18 to 0.4 & 1.2 & 0.73 \\
\hline Bubble point pressure & 17.409 & $16.665-25.842$ & 16.685 & 7.612 \\
\hline Oil formation volume factor @ bp $\quad\left[\mathrm{m}^{3} / \mathrm{std} . \mathrm{m}^{3}\right]$ & 1.256 & $1.436-1.755$ & 1.52 & 1.231 \\
\hline Solution gas oil ratio @ bp $\quad\left[\right.$ std. $\left.\mathrm{m}^{3} / \mathrm{std} . \mathrm{m}^{3}\right]$ & 140.35 & $130-224$ & 155.8 & 47.2 \\
\hline Temperature & 121.1 & $104.4-110$ & 110 & 111.1 \\
\hline Asphaltene content & 1.24 & $1.3-1.5$ & $2-3$ & 0.0 \\
\hline Sulfur content & 0.0 & $0.7-1.2$ & 9.5 & 0.0 \\
\hline
\end{tabular}

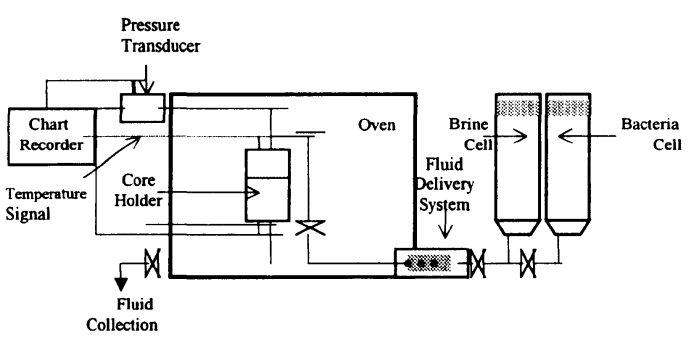

Fig. 1 Core Flooding Apparatus

spaced 16 perforations of $1.6 \mathrm{~mm}$ diameter each, placed in a single row. The tube was placed centrally across the bottom of the bioreactor.

\section{2. 2. Core Flooding Apparatus}

The schematic diagram of the core flooding apparatus is shown in Fig. 1. Two fluid accumulators are connected to a variable rate injection pump. The core holder is placed in a variable temperature oven. Pressure and temperature transducers are connected at both ends of the core inside the core holder. A chart recorder and a digital pressure recorder are connected to the temperature transducer and pressure transducer respectively.

\section{2. 3. Computerized Image Analyzer}

A computerized image analysis system was used to measure concentrations of bacteria in the culture for both the injected and the effluent water samples. The basic system consists of a high-resolution video camera on an optical microscope, an image processor, a Pentium PC, a high-resolution image monitor, and a high-resolution text monitor. The image is visualized with the video camera through a microscope lens. As soon as binary images are produced from an accepted microphotograph, a feature count can be performed. This may be simply accomplished by selecting the desired bit plane and activating the count option.

\section{2. 4. Electrical Cell}

The cell, shown in Fig. 2, consisted of a small rectangular box made from Perspex. Two copper electrodes of $3 \mathrm{~mm}^{2}$ were fixed inside the box and an electric field of $5 \mathrm{~V}$ was maintained between the two electrodes. When the box was filled with a microbial

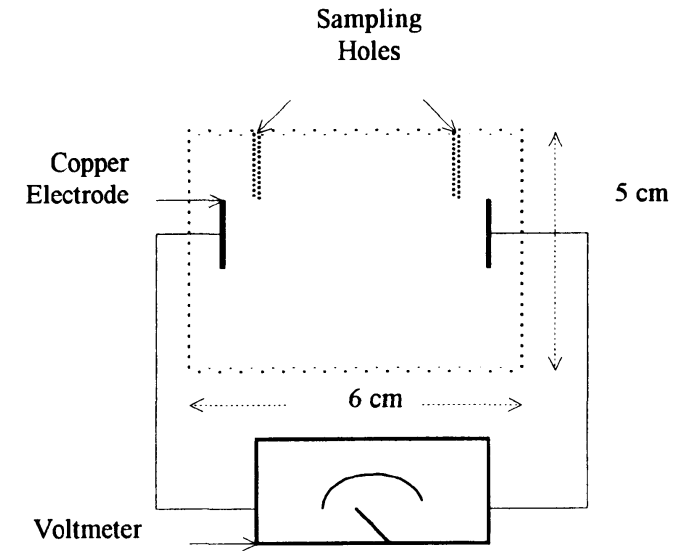

Fig. 2 Schematic Drawing of Bacteria Electrical Charge

solution containing a known amount of bacteria, samples were withdrawn near the anode and the cathode by means of a syringe via openings at the top of the cell. The samples were observed under the microscope to investigate the effect of the electric field on the bacteria. The main objective of using this electrical cell was to determine the type of charges if any on each of the two bacteria species (round and rod type) used in this study.

\section{2. 5. Interfacial Tension Apparatus}

The spinning drop Model 500 interfacial tensiometer was used in this project. The apparatus includes a variable temperature air bath so that reservoir temperatures can be emulated.

\section{3. Experimental Procedure}

Initial tests involved the growth of bacteria in the air curtain bioreactor under a $22^{\circ} \mathrm{C}$ room temperature. A $10 \mathrm{~g} / 4000 \mathrm{~m} l$ of the nutrient is added to the microbial solution. The next step is to observe the bacteria growth as a function of time. To determine if the bacteria are aerobic or anaerobic, a sample of microbial solution is put in a smaller bioreactor and $\mathrm{N}_{2}$ is bubbled through the microbial solution. To test the electrical charges of the bacteria, a $100 \mathrm{ml}$ microbial solution containing a known amount of bacteria samples is placed in the electric cell. The system is subjected to a $5 \mathrm{~V}$ field and samples were withdrawn near the anode 
and the cathode after $1 \mathrm{~h}$. The samples are observed under the microscope to investigate which type of bacteria was attracted to either the anode or cathode.

The spinning drop apparatus was used to study the interfacial tension of the four crude oil samples and nutrient-rich brine containing bacteria. The spinning drop apparatus includes a capillary tube, into which an aqueous microbial solution is injected, followed by a small drop of oil. The fluids fill completely the capillary tube. The oil and nutrient-rich brine microbial solution are mixed together in the capillary tube and shaken well. The mixed fluids are then kept for $48 \mathrm{~h}$ to reach equilibrium and minimize any interactions between the oil and bacteria before using them in IFT measurements. A reduction of the final volume of the oil drop was observed which confirms the fact that bacteria did utilize hydrocarbon.

The limestone cores were dried at $80^{\circ} \mathrm{C}$ for $72 \mathrm{~h}$. Each core was evacuated for $12 \mathrm{~h}$ and saturated with a $5 \mathrm{wt} \%$ brine solution. During this step, we measured the volume of water required to completely saturate a core in order to determine its pore volume and porosity. Relatively large diameter cores $(3.81 \mathrm{~cm})$ were prepared and, by applying silver coating, a tight fit inside the core holder was obtained. Each core was then flooded at a high rate with the $\mathrm{AH}$ crude until no further brine was produced. The residual brine saturation for each core was calculated from the recovered effluent brine volumes. The cores were then flooded individually with the same brine ( $5 \mathrm{wt} \%$ salt) used for the saturation step until all oil production was complete (water cut $=100 \%$ ). The residual oil saturation from the volume of oil produced for each core and the initial absolute core permeability to brine were calculated for each core. Then, the previously prepared nutrient-rich microbial solution was injected into the core. A sample of injected microbial solution was tested for bacteria count. All produced fluids are collected and bacteria counts are measured as a function of pore volume injected to evaluate the growth of microorganisms. Furthermore, oil and water production rates, the $\mathrm{pH}$, and the viscosity of the produced fluids are measured. These data are used to evaluate the incremental effect of bacteria flooding on oil recovery. Fluid samples, from both the inlet and the outlet of the core holder, were tested using the Computer Image Analyzer to investigate the effect of the porous media's harsh environment on the bacteria. Microphotographs of the inlet microbial solution and effluent fluid were taken to assess the mechanism of bacterial oil recovery.

\section{Results and Discussion}

\section{1. Bacteria Identification}

The microbial culture used in this project is naturally occurring, non-pathogenic and not genetically engi- neered. Dimensions are 1.5 to $6 \mu \mathrm{m}$ in length and 0.1 to $0.4 \mu \mathrm{m}$ in width. To study the behavior of the microorganisms under an electric field, a microbial solution containing $10^{5} \mathrm{cells} / \mathrm{m} l$ of bacteria was investigated in the electrical cell and an electric field of $5 \mathrm{~V}$ was maintained in the cell. Samples were withdrawn from the cell near the electrodes, and microphotographs of these samples were taken using the Computer Image Analyzer (CIA). The microphotographs showed new phenomenon, not previously reported. The negative pole attracted all the rode shaped bacteria and the rounded shape bacteria gathered near the positive pole. From this observation, one can conclude that the rounded shape bacteria are negatively charged and the rod shape bacteria are positively charged. No significant differences were observed on the measured $\mathrm{pH}$ prior to and after placing the microbial solution in the electrical cell and applying the electrical field.

A $100 \mathrm{ml}$ of nutrient-rich microbial solution was placed in the small size aerated bioreactor. Air was bubbled through the system for $2 \mathrm{~h}$. Then, a sample was taken for bacteria count using the CIA. The initial bacteria count was found to be equal to $99 \times 10^{3}$ cells $/ \mathrm{ml}$. At this point, air was disconnected and nitrogen with a $99.5 \%$ purity was bubbled through the system for $5.5 \mathrm{~h}$, then another bacteria count was taken and found to be equal to $128 \times 10^{3}$. The $29 \%$ increase in the bacteria count demonstrated the ability of the bacteria to survive in the medium with little oxygen. Therefore we could classify these bacteria as facultative anaerobic type.

\section{2. Bacteria Growth}

The same type of bacteria employed in this study was earlier tested for growth under different temperature and salinity conditions ${ }^{9}$. The most rapid growth was observed to be at temperature close to $80^{\circ} \mathrm{C}$. All the studied cases used $10 \%$ crude oil and 5\% salinity. The growth rate indicated both viability and enhanced bacterial growth at elevated temperatures. A brine nutrient-rich solution $(5 \% \mathrm{NaCl})$ was mixed with crude oil in the cylindrical bioreactor at a temperature of $45^{\circ} \mathrm{C}$ for one week. Compressed air was bubbled through the mixture to insure continuous mixing of the oil and microbial solution. Oil was initially heated to $80^{\circ} \mathrm{C}$ for $72 \mathrm{~h}$ to eliminate evaporation effects. Around $34 \%$ of the original weight of the oil were lost during this process, which indicate that the bacteria used in this project metabolize the crude oil at the aerobic condition.

\section{3. Interfacial Tension Measurement}

The four types of crude oil were initially used to investigate the interfacial activity of the microorganism at different temperatures. The St crude was the only crude that contains sulfur (around 9.5\%). All measurements were carried out at temperatures between 35 $90^{\circ} \mathrm{C}$ and the salinity was kept constant throughout at 


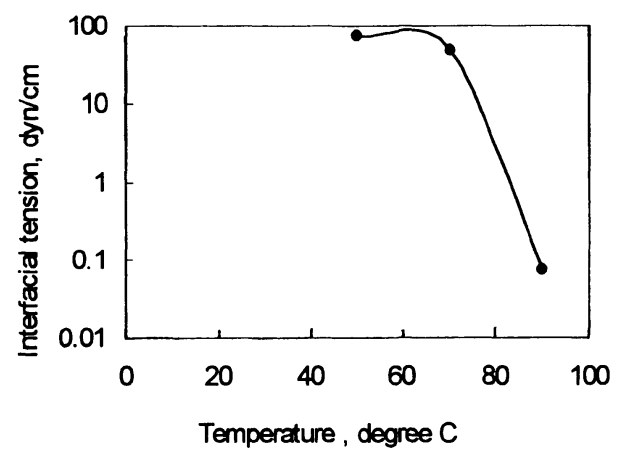

Fig. 3 Effect of Temperature on the Interfacial Tension, UAD Crude

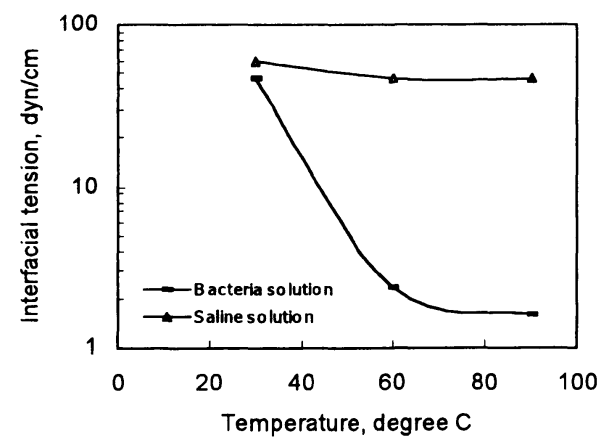

Fig. 4 Effect of Temperature on the Interfacial Tension, AH Crude

$10 \mathrm{wt} \%$. Bacteria concentration counts used for all IFT measurements were equal to $3 \times 10^{3} \mathrm{cells} / \mathrm{ml}$. Figure 3 shows the effect of temperature on the IFT of UAD crude. Clearly at low temperatures, the microbes have insignificant activity, which results in no side products and no alteration of IFT. At the elevated temperature $60^{\circ} \mathrm{C}$, an abrupt decrease in the interfacial tension of the system coupled with gas bubbles evolving from the microbial solution was observed. This indicates the increased activity of the microorganisms. The decrease of IFT is around $99 \%$ of the original value. Two systems were tested employing the AH crude oil; a bacteria-free solution consisting only of a $10 \% \mathrm{NaCl}$ solution and a bacteria-containing solution. Results are shown in Fig. 4. These results clearly demonstrate that bacteria metabolism is essential in the reduction of IFT at a relatively high temperature of around $60^{\circ} \mathrm{C}$. Increasing the temperature from 24 to $85^{\circ} \mathrm{C}$ resulted in reduction of IFT from 70 to 2 dyn/cm, as shown in Fig. 4. To demonstrate the metabolism of bacteria in oil, a small drop of the $\mathrm{AH}$ crude was added to the microbial solution. After one day, the drop disappeared completely. The previous phenomenon demonstrates that the bacteria used in this project consume hydrocarbons and can be used for the purpose of biodegradation. Results of the measure-

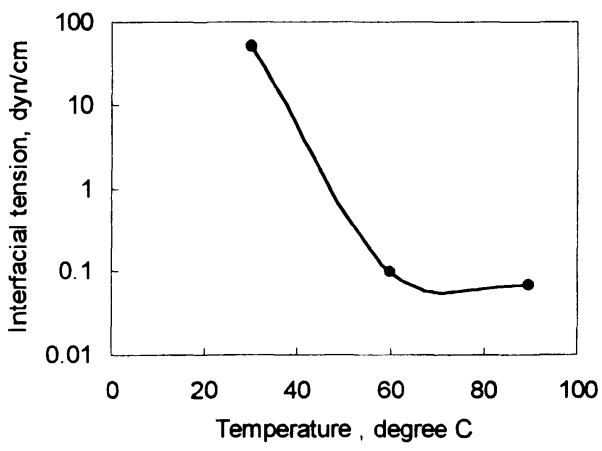

Fig. 5 Effect of Temperature on the Interfacial Tension, UZ Crude Oil and Bacteria Solution

ment of IFT employing the UZ crude indicate the reduction of IFT starts gradually at a slightly lower temperature than $60^{\circ} \mathrm{C}$ as shown in Fig. 5. The microbial solution did not significantly affect the IFT of the St crude oil. The presence of sulfur in the oil seems to reduce or eliminate the microbial metabolism, thus preventing the bacteria from producing a surfactant. The sulfur effect will be investigated further in the next phase of this project.

\section{4. Core Flooding}

Six different limestone cores were used to assess the viability of microorganisms in a tertiary flooding process. Permeability and porosity of the employed cores range between $0.5-64 \times 10^{-3} \mu \mathrm{m}^{2}$ and $0.06-0.26 \times$ $10^{-3} \mu \mathrm{m}^{2}$ as indicated in Table 1 . Microbial solution was injected into the core and incubated for $1 \mathrm{~h}$ in order for the cells to be able to adapt to this new environment. A summary of the core flooding results is presented in Table 3. The results prove clearly that microbial flooding is capable of displacing and recovering addition oil over water flooding provided that reasonable oil saturation present at the start of the microbial flooding. For example, in the case of core BF2, microbial flooding recovered $92 \%$ of water flooding remaining oil and on the average $67 \%$ of water flooding remaining oil was recovered by microbial flooding. In addition to that, microbial flooding resulted in selective plugging of high permeability zones, which resulted in reduction of core permeability as presented in Table 3. A complete discussion of a selective plugging phenomenon is presented in section 3.5. Figure 7, for core $\mathrm{BF} 3$ that has a pre-microbial flooding absolute permeability of $19 \times 10^{-3} \mu \mathrm{m}^{2}$, is a typical plot for tertiary floods conducted. Microbial flooding started after water flooding at $45 \%$ residual oil saturation. As a result of microbial action, the residual oil saturation dropped to around $11 \%$.

These results are in contrast with previous investigators (Jenneman ${ }^{14)}$ and Raiders et al. ${ }^{19)}$ ) who reported that

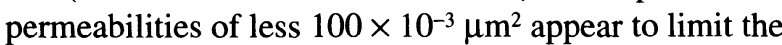
ability of microbes to penetrate the porous media, pro- 
Table 3 Summary of Core Flooding Results

\begin{tabular}{ccccccc}
\hline Core No. & Code & $\begin{array}{c}S_{\text {orw }}^{\text {a) }} \\
\text { [fraction] }\end{array}$ & $\begin{array}{c}S_{\text {orb }}^{\text {b) }} \\
{[\text { fraction] }}\end{array}$ & $\begin{array}{c}K_{\mathrm{c} \text { c) }} \\
{\left[10^{-3} \mu \mathrm{m}^{2}\right]}\end{array}$ & $\begin{array}{c}K_{\mathrm{f}}^{\mathrm{d})} \\
{\left[10^{-3} \mu \mathrm{m}^{2}\right]}\end{array}$ & $\begin{array}{c}\text { Flow rate } \\
{[\mathrm{m} l / \mathrm{min}]}\end{array}$ \\
\hline 1 & BF1 & 0.55 & 0.36 & 2.66 & 0.66 & 0.77 \\
2 & BF2 & 0.42 & 0.03 & 64.0 & 20.74 & 1.0 \\
3 & BF3 & 0.45 & 0.11 & 19 & 2.40 & 1.2 \\
4 & BF5 & 0.48 & 0.11 & 1.7 & 0.60 & 1.78 \\
5 & S4 & 0.25 & 0.24 & 23.9 & 23.8 & 2.5 \\
6 & SF5 & 0.35 & 0.16 & 0.06 & 0.05 & 2.5 \\
\hline
\end{tabular}

a) $S_{\text {orw }}=$ Residual oil saturation after water flooding. b) $S_{\text {orb }}=$ Residual oil saturation after bacteria flooding. c) $K_{\mathrm{i}}=$ Pre-bacteria flood core permeability. d) $K_{\mathrm{f}}=$ Post-bacteria flood core permeability.

Temperature $=80^{\circ} \mathrm{C}$.

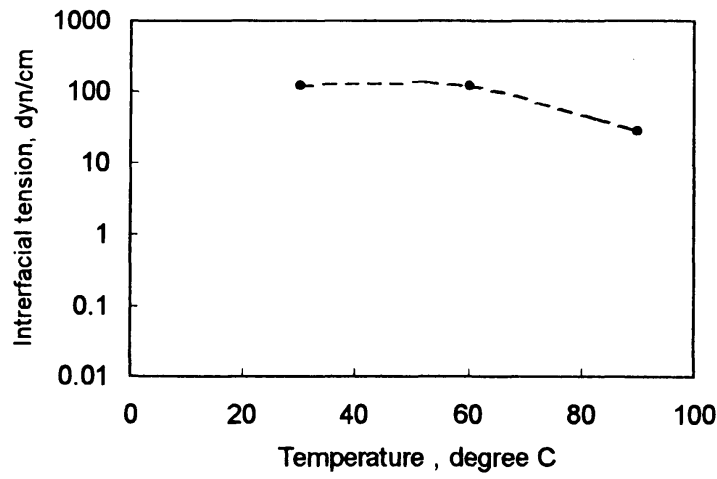

Fig. 6 Effect of Temperature on the Interfacial Tension, St Crude

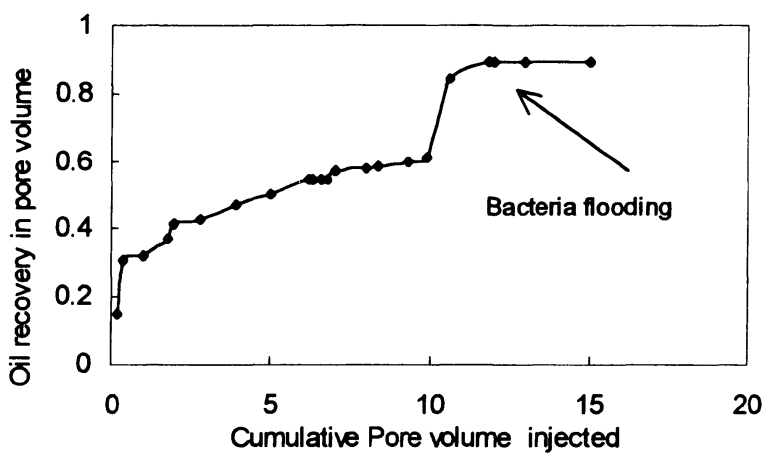

$K_{\mathrm{i}}=19 \times 10^{-3} \mu \mathrm{m}^{2}$, flow rate $=1.2 \mathrm{ml} / \mathrm{min}$, temperature $=80^{\circ} \mathrm{C}$.

Fig. 7 Oil Recovery vs. Pore Volume Injected for Core \# BF3

liferate and metabolize. An oil bank was generated after the core had been flooded with cells. The postbacterial flooding permeability did drop to $2.4 \times 10^{-3}$ $\mu \mathrm{m}^{2}$, a substantial reduction $(87 \%)$ as a result of bacteria flooding. Figure 8 shows the tertiary flooding response of core BF5. The left y-axis plots tertiary oil recovery as a percent of post water flood residual oil saturation and the right $y$-axis shows the pressure drop across the core, both plotted versus the cumulative injected pore volume of microbial solution. This core is very tight with a permeability of $1.7 \times 10^{-3} \mu \mathrm{m}^{2}$.

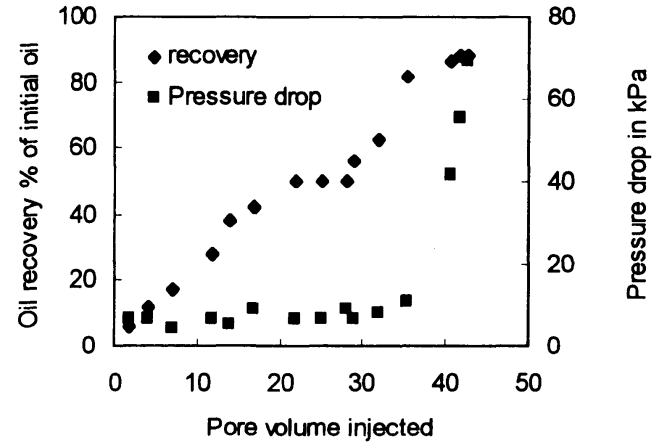

$K_{\mathrm{i}}=1.7 \times 10^{-3} \mu \mathrm{m}^{2}$, flow rate $=1.78 \mathrm{~m} / / \mathrm{min}$, temperature $=80^{\circ} \mathrm{C}$.

Fig. 8 Oil Recovery $v s$. Pore Volume Injected for Core

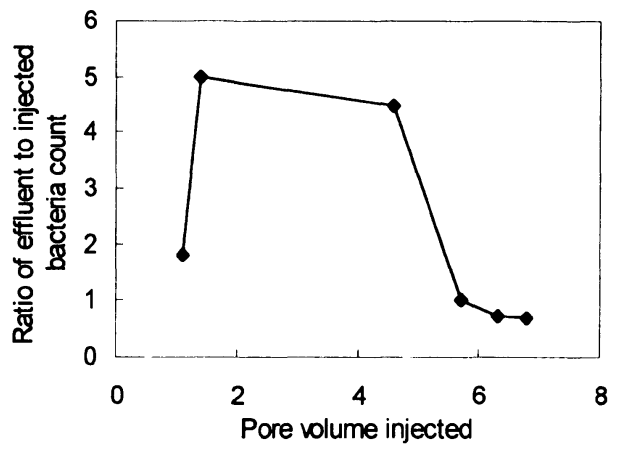

Flow rate $=1.78 \mathrm{ml} / \mathrm{min}$, temperature $=80^{\circ} \mathrm{C}$

Fig. 9 Transport of Bacteria through Core \# BF5

The same phenomenon of oil bank forming was observed. At a late stage of the flood, after the majority of incremental oil was recovered, a sudden increase in the pressure drop across the core was observed as indicated in Fig. 8. Bacteria count as a function of pore volume injected peaked initially after 1.2 of pore volume injected, as shown in Fig. 9, then gradually dropped to below initial injection microbial solution concentration. For core BF5, microbial solution flooding started at $S_{\text {orw }}$ (water flood residual saturation) of $47 \%$ of the pore volume and ceased at the final $S_{\text {orb }}$ 


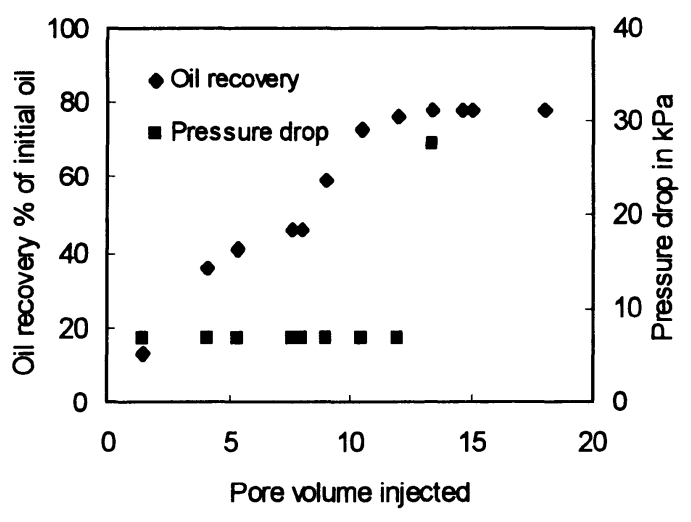

$K_{\mathrm{i}}=2.66 \times 10^{-3} \mu \mathrm{m}^{2}$, flow rate $=0.77 \mathrm{ml} / \mathrm{min}$, temperature $=80^{\circ} \mathrm{C}$.

Fig. 10 Pore Volume Injected vs. Oil Recovery for Core \# BF1

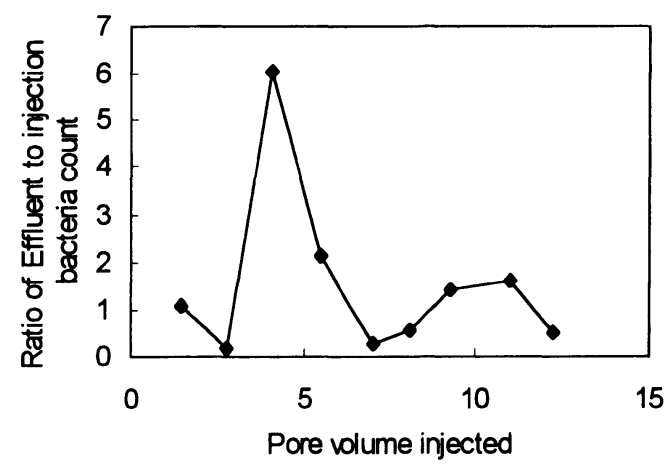

Flow rate $=0.77 \mathrm{ml} / \mathrm{min}$, temperature $=80^{\circ} \mathrm{C}$.

Fig. 11 Transport of Bacteria through Core \# BF1

(bacteria flood residual oil) of $11 \%$ pore volume. The permeability of the core dropped from $1.7 \times 10^{-3} \mu \mathrm{m}^{2}$ initially to $0.6 \times 10^{-3} \mu \mathrm{m}^{2}$ at the end of the flood, which amount to a $65 \%$ permeability reduction. The bacteria flood performance of core BF1 is shown in Fig. 10, which demonstrates the oil banking phenomena and sudden increase in the pressure drop across the core BF1 sample later in the flooding process. Microbial solution flooding started at $S_{\text {orw }}$ of $55 \%$ of the pore volume and stopped at the final $S_{\text {orb }}$ of $36 \%$. The permeability of the core BF1 dropped from $2.66 \times 10^{-3} \mu \mathrm{m}^{2}$ to $0.66 \times 10^{-3} \mu \mathrm{m}^{2}$ at the end of the flood, a $75 \%$ reduction. Microbial solution concentration as function of pore volume injected for core BF1 is shown in Fig. 11. The peak of concentration was observed to be at 4.8 pore volumes injected. Figure 12 shows the oil recovery and pressure drop across the core BF2. This run again confirmed the phenomenon of oil banking and pressure rising at later stages of the flooding process for relatively high-permeability cores $\left(64 \times 10^{-3}\right.$ $\mu \mathrm{m}^{2}$ ). The microbial solution flooding was initiated at $S_{\text {orw }}$ of $42 \%$ of pore volume and completed at $S_{\text {orb }}$ of $3 \%$ of pore volume. A permeability reduction of $43 \%$ was

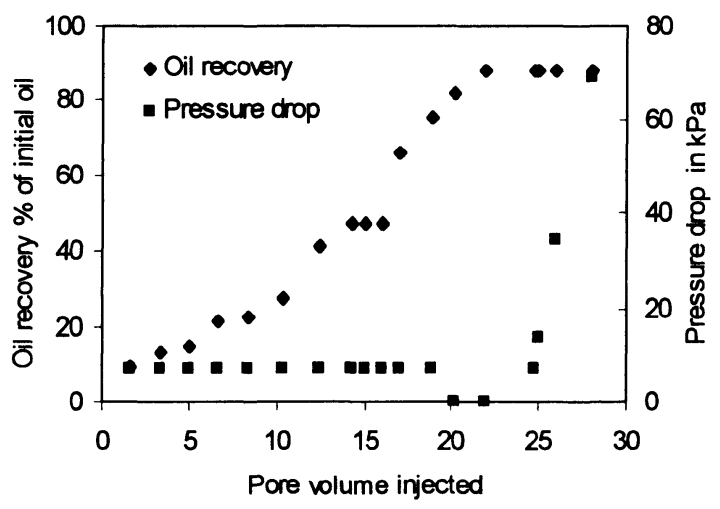

$K_{\mathrm{i}}=64 \times 10^{-3} \mu \mathrm{m}^{2}$, flow rate $=1 \mathrm{ml} / \mathrm{min}$, temperature $=80^{\circ} \mathrm{C}$.

Fig. 12 Pore Volume Injected vs. Oil Recovery for Core \# BF2

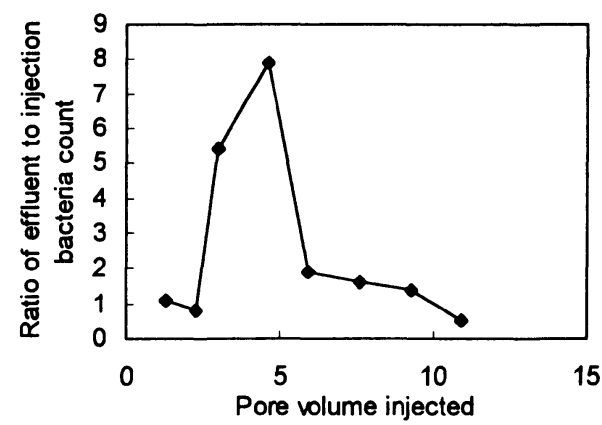

$K_{\mathrm{i}}=64 \times 10^{-3} \mu \mathrm{m}^{2}$, flow rate $=1 \mathrm{ml} / \mathrm{min}$, temperature $=80^{\circ} \mathrm{C}$.

Fig. 13 Transport of Bacteria through Core \# BF2

obtained due to microbial solution injection. The transport of bacteria through core BF2 is shown in Fig. 13. The same phenomenon of microbial solution concentration peaking and then dropping below initial concentration at the end of the flood was observed. Microbial solution flooding of core S4 resulted in marginal success in terms of $S_{\text {orw }}$ reduction. The flood was started at a very low oil saturation of $25 \%$ of pore volume which indicated that the microorganisms were not able to generate an oil bank, i.e. there was not enough in situ oil to form an oil bank. This run seems to suggest that there has to be a minimum initial oil saturation for MEOR floods to be successful. All the other tested cores clearly showed an improvement in oil recovery with the exception of core S4.

3. 5. Observations Regarding Mechanisms of MEOR

The metabolism of the bacteria with oil results in the production of free gas as observed during IFT measurements. This phenomenon was confirmed during the flooding experiments where the flow suddenly stopped due to the increase in backpressure as a result of the presence of free gas. The free gas phase normally decreases residual oil saturation. This observation is 


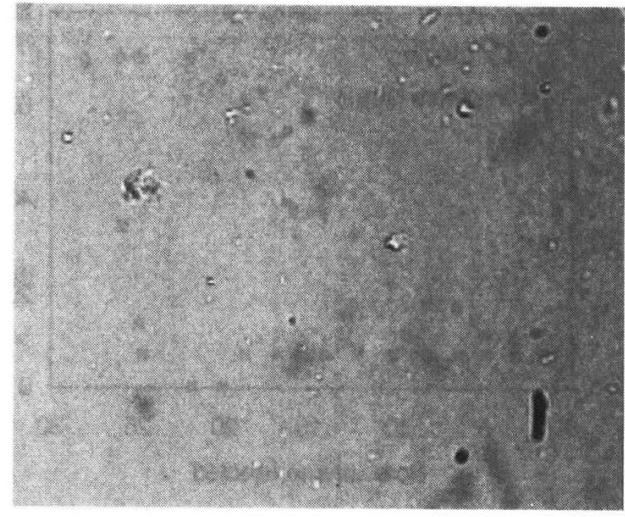

Fig. 14 Microphotograph Showing Inlet Bacteria Concentration

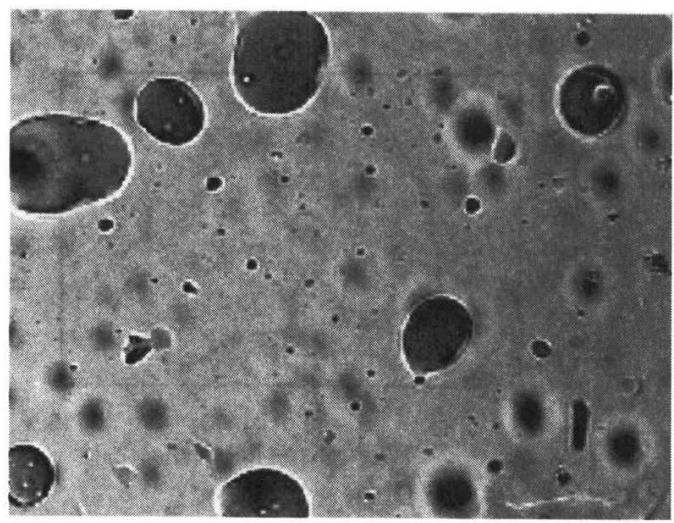

Fig. 15 Microphotograph Showing Bacteria Concentration after Flooding and the Presence of Microemulsion $(\times 1000)$

in conformity with that of Kyte et al. ${ }^{22)}$ who concluded that lower residual oil saturation were obtained when gas was present compared to floods performed in the absence of gas. Also, Chisholm et al. ${ }^{11)}$ concluded that the production of bio-gas decreases the residual oil saturation due to relative permeability changes associated with the creation of free gas phase in the sandstone core.

The second mechanism observed in these experiments is the formation of microemulsions. Figure 14 shows a computer image of water droplets obtained from the inlet of core $\mathrm{BF} 2$ at the beginning of microbial solution flooding and Fig. 15 shows the image of water droplet obtained from the outlet point immediately after breakthrough of the oil bank. As can be observed in Fig. 15, bacteria form oil in water microemulsion by extracting oil droplets and partitions themselves inside and at the periphery of the oil phase causing enhancement and stability of the emulsion. An important factor in the emulsification is the in situ surfactant production by the microorganism as confirmed by the measurements of IFT for all tested crudes except that of the St oil. It is interesting to note that

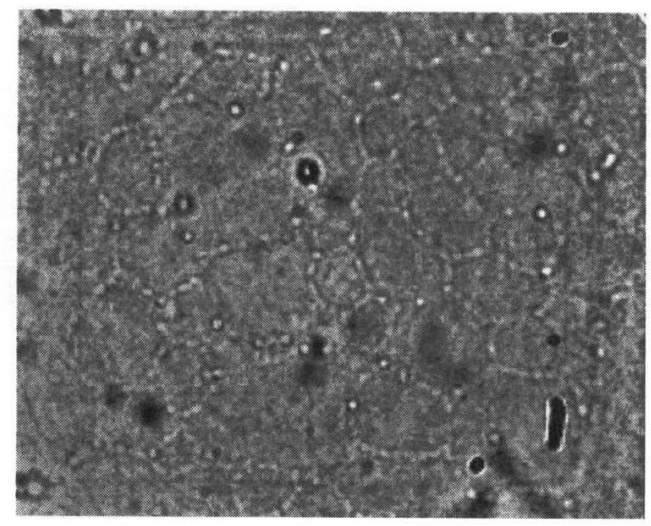

Fig. 16 The Sessile Bacteria Plugging the Pore Space $(\times 1000)$

the typical problem of surfactants adsorbing on the surface of reservoir rocks and especially carbonate rocks, which decreases the concentration of surfactant below that required for IFT reduction, is quite limited for MEOR since the surfactant is produced in situ.

The third mechanism responsible for the improvement of oil recovery is the selective plugging. Selective plugging of high permeability zones by these microorganisms can improve sweep efficiency. Two types of microorganism plugging have been identified: plugging by viable cells and plugging by non-viable microbes. Non-viable cells (dead bacteria) were observed for the rod bacteria type used in this work which could not tolerate the reservoir conditions. They act as particulate agents, since they don't produce slime. Viable microorganisms have the ability to adhere to the rock surface and produce extra cellular material, which cover the cell and the rock surface forming a polymer film ${ }^{11)}$. This phenomenon was observed and is shown in Fig. 16. It is an electronic image of the outlet microbial solution dried on the surface of glass. The bacteria is forming sessile (attached) that occupy the pore space. The pores surface characteristics are changed by the presence of sessile bacteria. This selective plugging will result in microscopic change in the limestone rock. Jenneman et al. ${ }^{23)}$ reported that bacteria are capable of producing enough biomass inside a rock core to produce significant permeability reduction $(60-80 \%)$.

Finally, the $\mathrm{pH}$ of the inlet and outlet microbial solutions were measured. No significant change was observed (inlet $\mathrm{pH}=8.76$ and outlet $\mathrm{pH}=8.83$ ). The viscosity of the injected microbial solution was 0.949 $\mathrm{cP}$ while the viscosity of the produced microbial solution was $0.99 \mathrm{cP}$. This indicates that the microbe did not alter the viscosity of the injected fluid and therefore the cells did not produce polymer soluble in the injection water. Therefore, the effects of the gas evolution, surfactant production, microemulsion formation, and selective plugging by bacteria is believed to contribute 
to the oil recovery in this project.

\section{Conclusions}

Based on the study, the following conclusions can be stated:

(1) An increase in oil recovery by tertiary injection of thermophilic bacteria obtained from UAE environment in limestone cores was observed.

(2) The mechanism for enhanced recovery seems to be through production of bio-surfactant, bio-gas, and biomass by the bacteria.

(3) Production of the bio-surfactant reduced the IFT for the AH, UZ, and UAD crudes. Presence of sulfur in the St crude oil hindered the interfacial activity of the bacteria.

(4) A successful MEOR flood was obtained even in a tight limestone core whose permeability was as low as $1.7 \times 10^{-3} \mu \mathrm{m}^{2}$ and a minimum oil saturation (at or above $25 \%$ ) is required for the success of the MEOR process.

\section{Acknowledgments}

Funding for this research was provided by the Abu Dhabi National Oil Co. (ADNOC). We would like to thank Saleh Ahmed, Khalid Rashid and Reyad Juma Saleh for performing the IFT measurments. Special thanks to Ibrahiem El-Magrabi for conducting the Image Analyzer tests and to Samir Al-Hardlu for performing the core flooding experiments.

\section{References}

1) Beckman, J. W., Ind. Eng. Chem., 4, (11), 23 (1926).

2) Zobell, C. E., "Bacteriological Process for Treatment of FluidBearing Earth Formation," USP 24133278 (1946).

3) Bryant, R. S., Lindsey, R. P., SPE/DOE 35356 presented at the Improved Oil Recovery Symposium, Tulsa, OK, Apr. 1996.

4) Dietrich, F. L., Brown, F. G., Maure, M. A., Zhou, M. A., SPE 36746 presented at the 1996 SPE Annual Technical Conference and Exhibition, Denver, Colorado, Oct. 1996.
5) Portwood, J. T., SPE 29518 presented at The Production Operations Symposium, OK, Apr. 1995.

6) Bryant, R. S., Bertus, K. M., Burchfield, T. E., Dennis, M., SPE/DOE 27751 presented at the SPE/DOE 9th Symposium on Improved Oil Recovery, Tulsa, OK, Apr. 1994.

7) Crawford, P. B., Prod. Monthly, 26, 2 (1962).

8) Cooper, D. G., Zajic, J. E., J. Ferment. Tech., 58, 83 (1980).

9) Al-Magrabi, I. M., Bin Agil, A. O., Chaalal, O., Islam, M. R., 2nd Annual Conf. on Water Technology and Environment, Doha, Qatar, Dec. 1997.

10) Rouse, B., Hiebert, F., Lake, L. W., SPE 24819 presented at the 67th Annual Technical Conference and Exhibition, Washington, D.C., Oct. 4-7, 1992.

11) Chisholm, J. L., Kashikar, S. V., Knapp, R. M., McInemey, M. J., Menzie, D. E., SPE 20481 presented at the 65th Annual Technical Conference and Exhibition, New Orleans, LA, Sept. 1990.

12) Yonebayashi, H., One, K., Enomoto, H., Chida, T., Hong, C.-X., Fujiwara, K., SPE 38070 presented at the 1997 SPE Asia Pacific Oil and Gas Conference, Kuala Lumpur, Malaysia, Apr. 1997.

13) Mayers, G. E., Samiroden, W. D., Prod. Monthly, (4), 22 (1967).

14) Jenneman, G. E., Knapp, R. M., Menzie, D. E., Revus, D. E., Clark, J. B., Monnecke, D. M., Proceedings 1982 International Symposium on Microbial Enhancement of Oil Recovery, NTIS, Springfield, VA, 1983, CONF-8205140, p.71-75.

15) Jenneman, G. E., Knapp, R. M., Mclinemey, M. J., Menzie, D. E., Revus, D. E., Soc. Pet. Eng. J., (2), 33 (1984)

16) Torbati, H. M., Raiders, R. A., Donalson, E. C., McInemey, M. J., Jenneman, G. E., Knapp, R. M., J. Ind. Microb., 227 (1986).

17) Jack, T. R., Thompson, B. G., DiBiasio, E., Proceedings 1982 International Conference on Microbial Enhancement of Oil Recovery, Afton, OK, May 1982, p.88-93.

18) Bryant, R. S., Douglas, J., Society of Petroleum Engineers International Symposium on Oilfield Chemistry, San Antonio, TX, Feb. 1987.

19) Raiders, R. A., Freeman, D. C., Jenneman, G. E., Knapp, R. M., McInemey, M. J., Menzie, D. E., SPE 14336 presented at the 60th Annual Meeting of the SPE, Las Vegas, NV, Sept. 1985.

20) Raiders, R. A., McInemey, M. J., Revus, D. E., Torbati, H. M., Knapp, R. M., Jenneman, G. E., J. Ind. Microb., 195 (1986).

21) Raiders, R. A., Maher, T. F., Knapp, R. M., McInemey, M. J., SPE 15600 presented at the 61 st Annual Meeting of the Society of Petroleum Engineers, New Orleans, LA, Oct. 1986.

22) Kyte, J. R., Stanclift, R. J. Jr., Stephen, S. C. Jr., Rapoport, L. A., Trans. AIME, 207, 215 (1956).

23) Jenneman, G. E., SPE 10789 presented at the 3rd SPE/DOE EOR Symposium, Tulsa, OK, Apr. 1982. 
要 旨

\section{バクテリアフラッディングによる UAE 石灰岩油層からの原油增進回収}

Abudulrazag Y. ZeKRI, Reyadh ALmeHAIDEB, Omar ChAALAL

Chemical \& Petroleum Engineering Dept., Faculty of Engineering, UAE University, P.O.Box 17555, Al-Ain, United Arab Emirates

比較的低コストの素材であるバクテリアを用いたUAE 石灰 岩油層からの原油増進回収について検討した。まず, UAEの 異なる四つの油田（AH，UZ, St, UAD）の原油と親熱性バク テリア溶液との間の界面張力に着目した検討を行った。地域の 水源から得られたバクテリアを用い, 温度 $30 \sim 100^{\circ} \mathrm{C}$, 塩濃度 $0 \sim 100,000 \mathrm{ppm}$ の範囲で検討し，栄養を与えない油層条件下 でバクテリア溶液によるフラッディング実験を行った。また， バクテリアやその増進回収機構のキャラクタリゼーションを行
つた。

実験室での検討の結果, 硫黄分リッチな St 原油の系以外で は, 高塩濃度, 高温の条件で急激な界面張力の低下が観測され た。検討したほとんどの系で, 界面張力は $40 \mathrm{dyn} / \mathrm{cm}$ から 0.07 $\mathrm{dyn} / \mathrm{cm}$ 程度にまで低下した。油層モデル条件下でのフラッデ イング実験では, 通算で孔げき容積の $15 \%$ ないし $20 \%$ 相当の 回収が平均的に達成された。

\section{Keywords}

Enhanced oil recovery, Laboratory test, Crude oil, Biomass 